\title{
Lignin Degrading System of Phanerochaete chrysosporium and its Exploitation for Degradation of Synthetic Dyes Wastewater
}

\author{
Shumaila Kiran ${ }^{1 *}$, Tayyaba Huma ${ }^{2}$, Fatima Jalal ${ }^{3}$, Tahir Farooq ${ }^{1}$, \\ Arruje Hameed ${ }^{4}$, Tahsin Gulzar ${ }^{1}$, Akbar Bashir ${ }^{1}$, Muniba Rahmat ${ }^{1}$, \\ Rubina Rahmat ${ }^{5}$, Muhammad Asim Rafique ${ }^{6}$
}

\author{
${ }^{1}$ Department of Applied Chemistry, Government College University Faisalabad, Pakistan \\ ${ }^{2}$ Department of Biotechnology and Bioinformatics, Government College University Faisalabad, Pakistan \\ ${ }^{3}$ Department of Zoology, Government College University Faisalabad, Pakistan \\ ${ }^{4}$ Department of Biochemistry, Government College University Faisalabad, Pakistan \\ ${ }^{5}$ Department of Physics, University of Punjab, Lahore, Pakistan \\ ${ }^{6}$ Department of Public Administration, Government College University Faisalabad, Pakistan
}

Received: 6 February 2018

Accepted: 27 March 2018

\begin{abstract}
Azo dyes are the main group of dyes used in different industrial applications. These dyes are highly toxic for aquatic life, so their removal is of utmost importance before they can be disposed of in a main water body. The present study focused on degrading/mineralizing the synthetic reactive dye wastewater. Initial experiments were done with four indigenous white rot fungi. P. chrysosporium (PC) showed more potential toward degradation of synthetic dye wastewater than other three fungal strains, so it was selected for further optimization of different fermentation parameters. Maximum decolorization (84.8\%) of reactive dye wastewater was obtained at $\mathrm{pH} 5$, inoculum size $4 \mathrm{~mL}$, and $30^{\circ} \mathrm{C}$. After optimizing experimental parameters, the effects of different nutritional factors like carbon and nitrogen sources were also studied. Decolorization of synthetic dye wastewater was increased from 84.8 to $89.2 \%$, when rice bran was used as an additional carbon source. However, no increase in decolorization of synthetic dye wastewater was observed in the presence of nitrogen supplements. The screened fungal strain decolorized the wastewater up to $90 \%$. The effect of different nutritional factors enhanced the degradation capability of the fungal strain under study. UV-visible and FTIR analyses confirmed the degradation of synthetic dye wastewater into simpler, non-toxic products.
\end{abstract}

Keywords: synthetic dye wastewater, Phanerochaete chrysosporium, mineralization, ligninolytic enzymes, effect of amendments, FTIR analysis

*e-mail: shumaila.asimch@gmail.com 


\section{Introduction}

Azo dyes comprise almost one-half of all synthetic dyes, find their applications in different industries like food, paper, textiles, leather, cosmetics, etc. Among them, the textile industry is the main consumer of these dyes in its different operations [1]. About $15-20 \%$ of the dyes used in textile industries remain unutilized and are discharged into water bodies without any prior treatment. Dyes may significantly affect photosynthetic activity and have a significant impact on human health, as well as other animals [2]. These dyes are stable toward light, so they tend to reside in environments for a long period of time, causing a serious threat to the environment [3]. The complete removal of harmful dyes is a major concern [4]. Different physical methods are in use, but they are not efficient as they convert pollution from one phase to another [5]. Although chemical processes are found to be more efficient than physical ones, they are either costlier or they may generate byproducts that are more toxic than their precursors. On the other hand, biological treatment using bacteria or fungi are striking choices as they could be economically viable, easy to use, and environmentally approachable [6]. Different contaminants could be efficiently mineralized using microbes [7]. A unique characteristic of fungi is their ability to produce several non-specific enzymes. These non-specific extracellular and/or exoenzymes enable aquatic fungi to attack structurally diverse organic compounds that correspond to different pollutant classes. Hence, these fungi may serve as a new resource to treat wastewater [8]. The present study is focused on the screening of four different strains of white rot fungi for the degradation of synthetic wastewater having notorious dyes. The screened fungal strain was used for subsequent studies.

\section{Materials and Methods}

\section{Chemicals}

All chemicals were purchased from a chemical store and were of analytical grade.

Reactive dyes were kindly provided by Sandal Dyestuff, Pvt. Ltd. Dye structures are given below:

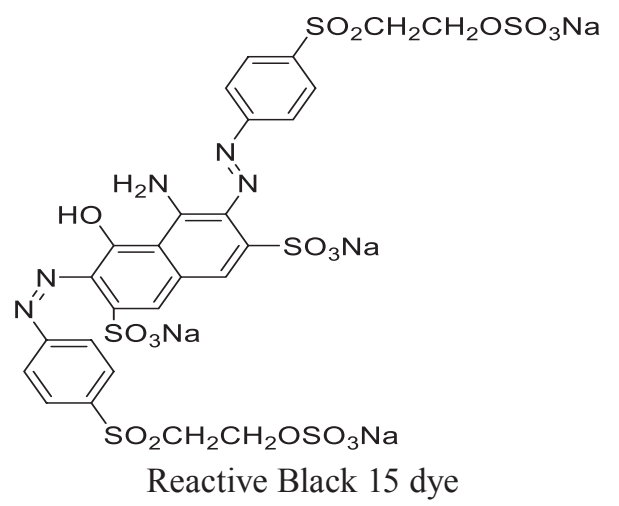<smiles></smiles><smiles>CC1=C(C(N)=O)C(O)=C(N=Nc2cc(Nc3nc(Cl)nc(Nc4ccc(S(=O)(=O)O[O-])cc4)n3)ccc2F)C(C)C1=O</smiles>

Lemon Yellow C-4 GL dye

\section{Preparing Synthetic Dye Wastewater}

Dye wastewater was prepared by mixing three reactive dyes (Reactive Blue, $140 \mathrm{mg} / \mathrm{L}$; Reactive V iolet, $152 \mathrm{mg} / \mathrm{L}$; and Reactive Yellow, $1212 \mathrm{mg} / \mathrm{L}$ ), hydrolysed starch (14 mg/L), sodium sulphate $(28 \mathrm{mg} / \mathrm{L})$, and sodium hydrogen phosphate $(28 \mathrm{mg} / \mathrm{L})$ in de-ionized water. $\mathrm{pH}$ of the sample material was set to 12 using $1 \mathrm{M} \mathrm{NaOH} / 0.5 \mathrm{M} \mathrm{H}_{2} \mathrm{SO}_{4}$. The reaction material was placed on a magnetic stirrer at $80^{\circ} \mathrm{C}$ for 90 minutes [4].

\section{Microorganisms}

The pure culture of four white rot fungi (WRF) $P$. ostreatus (PO), P. chrysosporium (PC), T. versicolor (TV), and G. lucidum (GL) were taken from an industrial biotechnology lab, UAF, and grown in potato dextrose agar (PDA) media slants $(\mathrm{pH} \mathrm{4.5}$, temperature $30^{\circ} \mathrm{C}$ ) for one week. The slants were preserved at $4^{\circ} \mathrm{C}$ in a refrigerator [9].

\section{Preparing Inoculum}

For preparing inocula, the $\mathrm{pH}$ of triplicate flasks having Kirk's nutrient medium was set to 4.5 with $0.1 \mathrm{M} \mathrm{NaOH} / 0.05 \mathrm{M} \mathrm{H}_{2} \mathrm{SO}_{4}$. The flasks were placed in an autoclave at $121^{\circ} \mathrm{C}$ for $15 \mathrm{~min}$. Fungal cultures from respective fungal slants were added in flasks. The flasks were placed in an incubator $(120 \mathrm{rpm})$ at $30^{\circ} \mathrm{C}$ for 5-7 days to get homogeneous spores [10].

\section{Experimental Protocol}

The flasks having $100 \mathrm{~mL}$ of dye wastewater and $100 \mathrm{~mL}$ of Kirk's medium ( $\mathrm{pH} 4.5$ ) were autoclaved for $15 \mathrm{~min}$. at $121^{\circ} \mathrm{C}$. The flasks were cooled and inoculated with $5 \mathrm{~mL}$ spore suspension of each fungus. The flasks were incubated at $30^{\circ} \mathrm{C}$ for 5 days. Supernatants were collected after centrifuging (1200 rpm for 10 mints) and absorbance was measured through a spectrophotometer 
at $\lambda_{\max }$ of $600 \mathrm{~nm}$. The results were recorded as the average of triplicates.

\section{Optimizing the Biodegradation Process}

Different environmental factors affect the microbial growth and their production [11]. Important growthrelated factors (conc. of synthetic dyes wastewater $0.01-0.05 \%$; pH 3-5; incubation temperature $20-40^{\circ} \mathrm{C}$; inoculation size $1-5 \mathrm{~mL}$ ) were studied. One factor at a time was varied while others were kept constant.

\section{Effect of Amendments}

After optimizing experimental parameters, the effects of different carbon sources (glucose, starch, glycerol, wheat bran, rice bran) and nitrogen sources (yeast extract, maize glutein $30 \%$, maize glutein $60 \%$, corn steep liquor, ammonium oxalate) was studied to determine their effects on the production of fungal enzymes and level of dye decolorizing capability of fungus under study.

\section{Decolorization Assay Via UV-Vis Spectroscopy}

The decolourization (\%) efficacy was evaluated by measuring absorbance use of a UV/Visible spectrophotometer at $600 \mathrm{~nm}$. The following formula was used:

Decolourization $(\%)=(\mathrm{I}-\mathrm{F}) / \mathrm{I}$ x 100

$\mathrm{I}=$ initial absorbance

$\mathrm{F}=$ Absorbance of decolorized medium

\section{Enzyme Study}

\section{Lignin Peroxidase (LiP) Assay}

$1 \mathrm{~mL}$ of tartarate buffer $(1 \mathrm{mM})$ of $\mathrm{pH} 3$ and $1 \mathrm{~mL}$ of veratryl alcohol $(1 \mathrm{mM})$ were added to $100 \mu \mathrm{L}$ of supernatant of treated wastewater. $500 \mu \mathrm{L}$ of $\mathrm{H}_{2} \mathrm{O}_{2}(0.2 \mathrm{mM})$ was added in the reaction mixture. The reaction progress was determined by measuring absorbance at $310 \mathrm{~nm}$ [12].

\section{Manganese Peroxidase (MnP) Assay}

$1 \mathrm{~mL}$ of sodium malonate $(50 \mathrm{mM})$ buffer of $\mathrm{pH}$ 4.5 and $1 \mathrm{~mL}$ of $\mathrm{MnSO}_{4}(1 \mathrm{mM})$ were added in $100 \mu \mathrm{L}$ of supernatant of treated wastewater. $500 \mu \mathrm{L}$ of $\mathrm{H}_{2} \mathrm{O}_{2}(0.1 \mathrm{mM})$ was added to the reaction mixture. The reaction progress was determined by measuring absorbance at $270 \mathrm{~nm}$ [13].

\section{Laccase Assay}

$1 \mathrm{~mL}$ of malonate buffer $(50 \mathrm{mM})$ or $\mathrm{pH} 4.5$ and $1 \mathrm{~mL}$ of 2,2'-azino-bis(3-ethylbenzothiazoline-6sulphonic acid (ABTS) $(1 \mathrm{mM})$ were added in $100 \mu \mathrm{L}$ of supernatant of treated wastewater. $500 \mu \mathrm{L}$ of $\mathrm{H}_{2} \mathrm{O}_{2}$ $(0.2 \mathrm{mM})$ was added to the reaction mixture. The reaction progress was determined by measuring absorbance at $436 \mathrm{~nm}$ [14].

\section{Spectral Studies}

The dye decolorization products were monitored by measuring the change in UV-vis spectra (from 200 to $800 \mathrm{~nm}$ ) by means of a UV-vis spectrophotometer (Agilent 8453), whereas degradation investigation was checked by FTIR [15].

\section{Results and Discussion}

\author{
Screening White Rot Fungi (WRF) \\ for Decolorization of Synthetic \\ Dye Wastewater
}

Four strains of white rot fungi i.e. P. ostreatus (PO), $P$. chrysosporium (PC), T. versicolor (TV), and $G$. lucidum (GL) were initially screened. As the time was increased, the increase in decolorization of synthetic dye wastewater was observed by all fungal strains under study. Maximum decolourization was observed on the $6^{\text {th }}$ day of incubation (Table 1). Among all fungal strains, P. chrysosporium (PC) showed maximum decolorization $(82.9 \%)$ of dye wastewater; therefore, $P$. chrysosporium (PC) was nominated as a superlative applicant for further investigational work. Though all lignin-cellulosic enzyme systems were found to be responsible in the decolourization of dye wastewater by all fungal species, lignin peroxidase (LiP) was found to be the main enzyme more than manganese peroxidase $(\mathrm{MnP})$ and laccase on the $6^{\text {th }}$ day of nurturing (Table 1). Previous work reported that white-rot fungi are the most active biodegradables of lignocellulosic materials than other microbes [9]. In a previous study, lignin in a tobacco stalk was degraded up to $53.75 \%$ by Phanerochaete chrysosporium in a period of 15 days. The main enzyme responsible for degradation was found to be laccase [16]. Previous studies assessed that ligninolytic enzymes like laccases and peroxidases cause lignin degradation via free radicals like $\mathrm{OH}$, which depolymerizes the phenolic and non-phenolic portions of lignin polymer, hence it mineralizes the whole lignin molecule [17].

\section{Effect of Synthetic Dye Wastewater Concentration}

Dye molecules act as a substrate for microbes up to a certain concentration. A high concentration of dye molecules may cause a decline in growth of microbes, as it may act as growth inhibitor [4]. When synthetic dye wastewater concentration was increased from $0.01-0.05 \%$, the percent decolourization gradually decreased. Lignin peroxidase enzyme was found 
Table 1. Screening of WRF cultures for decolorizing synthetic dye wastewater

\begin{tabular}{|c|c|c|c|c|c|c|c|c|}
\hline \multirow{2}{*}{ WRF } & \multicolumn{4}{|c|}{ Decolorization (\%) \pm S.E } & \multicolumn{2}{c|}{ Enzyme activity (U/mL) \pm S.E } & Cell dry wt. \\
\cline { 2 - 9 } & Day-2 & Day-4 & Day-6 & Day-8 & Lac & MnP & LiP & 1.09 \\
\hline PC & $49.7 \pm 0.51$ & $62.1 \pm 0.5$ & $82.9 \pm 0.54$ & $60.1 \pm 0.5$ & $23.3 \pm 0.55$ & $33.3 \pm 0.5$ & $157.5 \pm 0.5$ & 0.12 \\
\hline PO & $40.2 \pm 0.52$ & $53.2 \pm 0.5$ & $65.9 \pm 0.52$ & $44.3 \pm 0.5$ & $25.1 \pm 0.55$ & $73.9 \pm 0.5$ & $24.5 \pm 0.5$ & \\
\hline TV & $20.8 \pm 0.52$ & $33.8 \pm 0.5$ & $42.6 \pm 0.51$ & $51.6 \pm 0.5$ & $20.4 \pm 0.5$ & $101.9 \pm 0.5$ & $95.2 \pm 0.53$ & 0.06 \\
\hline GL & $16.5 \pm 0.53$ & $31.8 \pm 0.5$ & $38.9 \pm 0.53$ & $46.1 \pm 0.5$ & $15.1 \pm 0.5$ & $99.7 \pm 0.52$ & $92.5 \pm 0.5$ & 0.04 \\
\hline
\end{tabular}

Table 2. Effect of concentration of synthetic dye wastewater on its decolorization (\%) and activities of ligninolytic enzymes of P. chrysosporium.

\begin{tabular}{|c|c|c|c|c|}
\hline Conc. $(\%) \pm$ S.E & $\begin{array}{c}\text { Decolourization } \\
(\%) \pm \text { S.E }\end{array}$ & $\begin{array}{c}\text { Laccase } \\
(\mathrm{U} / \mathrm{mL}) \pm \text { S.E }\end{array}$ & $\begin{array}{c}\text { MnP } \\
(\mathrm{U} / \mathrm{mL}) \pm \text { S.E }\end{array}$ & $\begin{array}{c}\text { LiP } \\
(\mathrm{U} / \mathrm{mL}) \pm \mathrm{S} . \mathrm{E}\end{array}$ \\
\hline 0.01 & $80.93 \pm 1.22$ & $14.9 \pm 0.41$ & $9.1 \pm 0.33$ & $83.3 \pm 0.48$ \\
\hline 0.02 & $55.675 \pm 1.23$ & $13.2 \pm 0.42$ & $8.5 \pm 0.36$ & $72.21 \pm 0.47$ \\
\hline 0.03 & $42.687 \pm 1.24$ & $12.5 \pm 0.46$ & $7 \pm 0.32$ & $64.53 \pm 0.46$ \\
\hline 0.04 & $32.448 \pm 1.24$ & $11.4 \pm 0.45$ & $6.1 \pm 0.35$ & $52.76 \pm 0.47$ \\
\hline 0.05 & $24.705 \pm 1.23$ & $9.5 \pm 0.45$ & $5.1 \pm 0.31$ & $43.21 \pm 0.46$ \\
\hline
\end{tabular}

to be more than laccase and manganese peroxidase enzymes (Table 2). Previous studies have shown that color elimination depends on the demolition of the chromophoric group. The ligninolytic system of the fungus attacks one dye molecule numerous times; a lesser quantity of the dye helps in the breaking of dye molecule while a larger quantity of the dye may cause a slower rate of dye deletion [18]. The dye molecule possesses $-\mathrm{SO}_{3} \mathrm{H}$ groups, which may hinder the growth of microbes at higher concentrations [19]. Initial dye concentrations usually range from 50-1000 $\mathrm{mg} / \mathrm{L}$. Decolorizations mainly depend on the nature of the microbe and type of dye in use [20].

\section{Effect of $\mathrm{pH}$ on Decolourization of Synthetic Dye Wastewater}

$\mathrm{pH}$ is one of the most important parameters affecting the growth of microbes. Microbes can grow in certain series of $\mathrm{pH}$ that favor nourishment and replication [21]. In general, fungi prefer to survive in acidic conditions, while bacteria breed in a neutral to alkaline atmosphere [22]. The effect of different $\mathrm{pH}$ (3.5-5.5) values on the decolorization (\%) of synthetic dye wastewater was examined. As $\mathrm{pH}$ increased from 3.5-4.5, decolourization $(\%)$ of synthetic dye wastewater was amplified from $41.60 \%$ to $83.07 \%$, but further increases in $\mathrm{pH}(5.5)$ resulted in a decrease in decolorization (46.5\%) (Table 3). Similarly, production of lignin-cellulosic enzymes (LiP, MnP, Laccase) was maximum at $\mathrm{pH}$ 4.5; however, production of $\mathrm{LiP}$ was found to be greater $(135.3 \mathrm{U} / \mathrm{mL})$ than the other two enzymes. After inoculation, the maximal decolorizing ability by white rot fungi was seen in acidic conditions. The rate of color deletion appeared to decline quickly under strongly acidic or alkaline situations, regardless of dye structure [23].

Table 3. Effect of $\mathrm{pH}$ on decolorization (\%) of synthetic dye wastewater and activities of ligninolytic enzymes of P. chrysosporium.

\begin{tabular}{|c|c|c|c|c|}
\hline $\mathrm{pH}$ & $\begin{array}{c}\text { Decolourization }(\%) \\
\pm \text { S.E }\end{array}$ & $\begin{array}{c}\text { Laccase } \\
(\mathrm{U} / \mathrm{mL}) \pm \text { S.E }\end{array}$ & $\begin{array}{c}\text { MnP } \\
(\mathrm{U} / \mathrm{mL}) \pm \text { S.E }\end{array}$ & $\begin{array}{c}\text { LiP } \\
(\mathrm{U} / \mathrm{mL}) \pm \mathrm{S} . \mathrm{E}\end{array}$ \\
\hline 3.5 & $41.63 \pm 1.29$ & $11.42 \pm 1.29$ & $10.59 \pm 1.23$ & $34.09 \pm 1.33$ \\
\hline 4.0 & $57.35 \pm 1.23$ & $13.22 \pm 1.23$ & $12.54 \pm 1.24$ & $65.6 \pm 1.34$ \\
\hline 4.5 & $83.07 \pm 1.29$ & $16.50 \pm 1.26$ & $14.04 \pm 1.23$ & $135.3 \pm 1.35$ \\
\hline 5.0 & $61.3 \pm 1.23$ & $14.33 \pm 1.25$ & $13.86 \pm 1.29$ & $72.36 \pm 1.29$ \\
\hline 5.5 & $46.5 \pm 1.23$ & $8.28 \pm 1.25$ & $10.10 \pm 1.23$ & $46.77 \pm 1.29$ \\
\hline
\end{tabular}


Table 4. Effect of inoculum size on decolorizing (\%) synthetic dye wastewater and activities of ligninolytic enzymes of P. chrysosporium.

\begin{tabular}{|c|c|c|c|c|}
\hline $\begin{array}{c}\text { Inoculum size } \\
(\mathrm{mL})\end{array}$ & $\begin{array}{c}\text { Decolourization } \\
(\%) \pm \mathrm{S} . \mathrm{E}\end{array}$ & $\begin{array}{c}\text { Laccase } \\
(\mathrm{U} / \mathrm{mL}) \pm \mathrm{S} . \mathrm{E}\end{array}$ & $\begin{array}{c}\text { MnP } \\
(\mathrm{U} / \mathrm{mL}) \pm \mathrm{S} . \mathrm{E}\end{array}$ & $\begin{array}{c}\mathrm{LiP} \\
(\mathrm{U} / \mathrm{mL}) \pm \mathrm{S} . \mathrm{E}\end{array}$ \\
\hline 1 & $28.25 \pm 1.31$ & $11.11 \pm 1.61$ & $10.9 \pm 1.51$ & $81.72 \pm 1.51$ \\
\hline 2 & $38.06 \pm 1.31$ & $14.03 \pm 1.62$ & $12.15 \pm 1.50$ & $90.32 \pm 1.50$ \\
\hline 3 & $44.17 \pm 1.33$ & $17.22 \pm 1.62$ & $15.54 \pm 1.49$ & $101.22 \pm 1.54$ \\
\hline 4 & $85.8 \pm 1.32$ & $14.32 \pm 1.63$ & $18.65 \pm 1.52$ & $138.23 \pm 1.49$ \\
\hline 5 & $45.16 \pm 1.31$ & $10.89 \pm 1.64$ & $16.49 \pm 1.53$ & $90.28 \pm 1.52$ \\
\hline
\end{tabular}

Table 5. Effect of temperature on decolorizing (\%) synthetic dye wastewater and activities of ligninolytic enzymes of P. chrysosporium.

\begin{tabular}{|c|c|c|c|c|}
\hline $\begin{array}{c}\text { Temperature } \\
\left({ }^{0} \mathrm{C}\right)\end{array}$ & $\begin{array}{c}\text { Decolourization } \\
(\%) \pm \text { S.E }\end{array}$ & $\begin{array}{c}\text { Laccase } \\
(\mathrm{U} / \mathrm{mL}) \pm \mathrm{S} . \mathrm{E}\end{array}$ & $\begin{array}{c}\text { MnP } \\
(\mathrm{U} / \mathrm{mL}) \pm \mathrm{S} . \mathrm{E}\end{array}$ & $\begin{array}{c}\text { LiP } \\
(\mathrm{U} / \mathrm{mL}) \pm \mathrm{S} . \mathrm{E}\end{array}$ \\
\hline 25 & $43.6 \pm 1.18$ & $4.12 \pm 1.43$ & $3.34 \pm 1.47$ & $45.32 \pm 1.46$ \\
\hline 30 & $84.8 \pm 1.19$ & $7.11 \pm 1.44$ & $8.11 \pm 1.46$ & $134.32 \pm 1.46$ \\
\hline 35 & $47.0 \pm 1.20$ & $5.81 \pm 1.46$ & $6.81 \pm 1.48$ & $48.92 \pm 1.47$ \\
\hline 40 & $38.47 \pm 1.21$ & $4.23 \pm 1.47$ & $4.11 \pm 1.47$ & $32.47 \pm 1.48$ \\
\hline
\end{tabular}

\section{Effect of Inoculum Size}

The effect of inoculum size was observed by keeping other parameters constant $\left(\mathrm{pH} 4.5,30^{\circ} \mathrm{C}\right)$. As inoculum size increased (\%), decolourization also increased, reaching a maximum value of $75.8 \%$ at inoculum size 4 and further increasing in inoculum size, decreasing its value to $45.16 \%$ (Table 4 ). A variation was noticed with the growth of different enzymes at the same value of inoculum size. LiP showed maximum production $103.23(\mathrm{U} / \mathrm{mL})$, while other enzymes like MnP and Laccase showed $18.68(\mathrm{U} / \mathrm{mL})$ $14.32(\mathrm{U} / \mathrm{mL})$ at inoculum size $4 \mathrm{~mL}$. Further increases in inoculum size brought a decline in percentage decolourization of $46.16 \%$ as well as enzyme growth reducing to $10.89(\mathrm{U} / \mathrm{mL}), 16.49(\mathrm{U} / \mathrm{mL})$, and 90.28 by laccase, MnP, and LiP. Most of the dyes can be degraded by liter-decomposing fungi. Their ligninolytic enzymes are involved in the degradation of textile wastewater having dyes. 4-5 $\mathrm{mL}$ of inoculum size is sufficient for maximum degradation of the textile wastewater with dyes $[24,25]$.

\section{Effect of Temperature on Decolourization of Synthetic Dyes Wastewater}

Temperature is a very important parameter that needs to be measured, as it has a major effect on microbial growth and their dye decolorizing ability as well. Microbes can grow over a range of temperature; however, there is an optimum temperature for maximum proliferation of microbes under study [26]. As temperature was increased from $25^{\circ} \mathrm{C}$ to $30^{\circ} \mathrm{C}$, the decolorization (\%) of synthetic dye wastewater increased from $43.6 \%$ to $84.8 \%$. A further increase in temperature caused a decline in decolorization (\%) of dye wastewater under study (Table 5). A similar trend was observed in production of enzymes by $P$. chrysosporium (PC). Lip production was maximum $(134.32 \mathrm{U} / \mathrm{mL})$ at optimized temperature $\left(30^{\circ} \mathrm{C}\right)$ than $\mathrm{MnP}$ and laccase. Different fungi have different optimal growth temperatures. Most of them grow at $25^{\circ} \mathrm{C}, 30^{\circ} \mathrm{C}$, or $35^{\circ} \mathrm{C}$ [27]. The optimal temperatures for enzymatic responses are typically higher, but the enzyme becomes thermally unstable at higher temperatures [3]. The optimal temperature may vary from microbe to microbe [4].

\section{Effect of Additional Carbon Sources}

Carbon is essential for microbial growth, and to offer the source for oxidants the microbe needs to degrade contaminants. Glucose, fructose, sucrose, etc. have been used in most investigations while also starch and xylan look to be valuable [28]. Various carbon sources like starch, glycerol, glucose, rice bran, and wheat bran were studied as an additional carbon source. Each additional carbon source showed a positive input toward decolorization of dye wastewater under study. Maximum decolorization (89.2\%) of synthetic textile dye wastewater by $P$. chrysosporium was obtained when rice bran was used as an additional carbon source to supplement other carbon sources. Production of LiP (146.81 U/mL) by $P$. chrysosporium was maximum when rice bran was added as an additional carbon source (Table 6). Other studies have observed the 
Table 6. Effect of additional carbon sources on decolorizing (\%) synthetic dye wastewater and activities of ligninolytic enzymes of P. chrysosporium.

\begin{tabular}{|c|c|c|c|c|}
\hline Carbon sources & $\begin{array}{c}\text { Decolourization } \\
(\%) \pm \text { S.E }\end{array}$ & $\begin{array}{c}\text { Laccase } \\
(\mathrm{U} / \mathrm{mL}) \pm \text { S.E }\end{array}$ & $\begin{array}{c}\text { MnP } \\
(\mathrm{U} / \mathrm{mL}) \pm \text { S.E }\end{array}$ & $\begin{array}{c}\text { LiP } \\
(\mathrm{U} / \mathrm{mL}) \pm \mathrm{S} . \mathrm{E}\end{array}$ \\
\hline Starch & $41.1 \pm 1.51$ & $15.89 \pm 1.48$ & $8.34 \pm 1.50$ & $94.93 \pm 1.47$ \\
\hline Glycerol & $44.7 \pm 1.52$ & $16.67 \pm 1.45$ & $8.07 \pm 1.49$ & $94.63 \pm 1.46$ \\
\hline Glucose & $48.4 \pm 1.53$ & $17.36 \pm 1.48$ & $8.32 \pm 1.53$ & $98.92 \pm 1.48$ \\
\hline Rice bran & $89.2 \pm 1.50$ & $18.25 \pm 1.45$ & $11.1 \pm 1.52$ & $146.81 \pm 1.43$ \\
\hline Wheat bran & $65.1 \pm 1.51$ & $16.20 \pm 1.48$ & $10.24 \pm 1.51$ & $131.62 \pm 1.42$ \\
\hline
\end{tabular}

Table 7. Effect of additional nitrogen sources on decolorizing (\%) synthetic dye wastewater and activities of ligninolytic enzymes of P. chrysosporium.

\begin{tabular}{|c|c|c|c|c|}
\hline Nitrogen Sources & $\begin{array}{c}\text { Decolourization }(\%) \\
\pm \text { S.E }\end{array}$ & $\begin{array}{c}\text { Laccase } \\
(\mathrm{U} / \mathrm{mL}) \pm \text { S.E }\end{array}$ & $\begin{array}{c}\text { MnP } \\
(\mathrm{U} / \mathrm{mL}) \pm \text { S.E }\end{array}$ & $\begin{array}{c}\text { LiP } \\
(\mathrm{U} / \mathrm{mL}) \pm \mathrm{S} . \mathrm{E}\end{array}$ \\
\hline Corn steep liquor & $53.23 \pm 1.52$ & $5.00 \pm 1.52$ & $3.73 \pm 1.42$ & $30.1 \pm 1.52$ \\
\hline Yeast extract & $55.91 \pm 1.51$ & $7.36 \pm 1.52$ & $4.65 \pm 1.41$ & $33.3 \pm 1.53$ \\
\hline Maize gluten $60 \%$ & $63.45 \pm 1.55$ & $8.4 \pm 1.53$ & $5.99 \pm 1.40$ & $50.3 \pm 1.55$ \\
\hline Ammonium oxalate & $80.08 \pm 1.55$ & $9.0 \pm 1.51$ & $6.77 \pm 1.42$ & $75.7 \pm 1.55$ \\
\hline Maize gluten $30 \%$ & $64.08 \pm 1.55$ & $6.47 \pm 1.52$ & $5.30 \pm 1.45$ & $38.5 \pm 1.56$ \\
\hline
\end{tabular}

effect of carbon sources on dye decolourization to optimize the yields of decolourization [29]. Researchers reported that decolourization is more effective in supplementing carbon sources [30].

\section{Effect of Additional Nitrogen Sources}

Various nitrogen sources were introduced to investigate the percentage decolorization of synthetic textile dye wastewater by $P$. chrysosporium (PC). The need of nitrogen for proliferation and particularly enzyme production varies distinctly between fungal cultures. It is well acknowledged that the production of lignin-cellulosic enzymes is more in nitrogen starvation [24], but a maximum $80.08 \%$ wastewater was decolorized when ammonium oxalate was used as a nitrogen source. Minimum 53.23\% decolourization was shown in the presence of corn steep liquor (Table 7). Researchers reported that Remazol black dye decolorization was markedly decreased in the presence of nitrogen sources like peptone, yeast extract, etc. [31], which might be because microbes could efficiently use dye carbon for their respiration and dye nitrogen to build their body proteins [32].

\section{Spectral Analysis}

UV-visible spectrum of unprocessed synthetic dye wastewater displayed a peak in the visible region $\left(\lambda_{\max }=600 \mathrm{~nm}\right)$. The treated synthetic dye wastewater showed a reduction in the height of spectral peak depicting absorption maxima, which confirmed


Fig. 1. UV-visible spectrum of synthetic dye wastewater before a) and after b) biological treatment by $P$. chrysosporium. 
the decolorization of dye wastewater under study. The appearance of spectral peak in the UV-region confirmed the degradation of synthetic dye wastewater under study (Fig. 1a-b). FTIR analysis was done to describe the metabolites of dye wastewater under study. FTIR spectrum of unprocessed synthetic dye wastewater exhibited peaks at 3344.59, 2352.21, and $1646.3 \mathrm{~cm}^{-1}$ for $-\mathrm{OH}$ stretch of phenol, $\mathrm{N}=\mathrm{N}$ stretch, and $\mathrm{C}=\mathrm{C}$ stretching of monosubstituted benzene ring (Fig. 2a), while FTIR analysis of the treated wastewater showed peaks at $3313.55 \mathrm{~cm}^{-1}$ for $-\mathrm{OH}$ stretch, $2945.51 \mathrm{~cm}^{-1}$ and $2834.66 \mathrm{~cm}^{-1}$ for $\mathrm{C}-\mathrm{H}$ stretching of alkyl benzene, $1460.07 \mathrm{~cm}^{-1}$ for $-\mathrm{C}-\mathrm{H}$ bending, 1127.51 and $1025.52 \mathrm{~cm}^{-1}$ for $\mathrm{C}-\mathrm{O}$ stretch, and $613.15 \mathrm{~cm}^{-1}$ for monosubstituted benzene ring (Fig. 2b). The appearance of peak at $3313.55 \mathrm{~cm}^{-1}$ indicated the formation of carboxylated products. The nonappearance of peaks amid 3400 to $3380 \mathrm{~cm}^{-1}$ for $-\mathrm{NH}$ stretch showed that no aliphatic and aromatic amines were produced by biological treatment. The peak distinctive of azo bond at $1646.3 \mathrm{~cm}^{-1}$ of dye was not present in the treated sample, indicating the degradation of dye wastewater to aromatic amines as midway products, which were further oxidized to simplified products. Researchers reported that using the fungal strain decolorization of dyes with the wavelength range $250-700 \mathrm{~nm}$ could be degraded to simpler products $[4,33]$.

a)

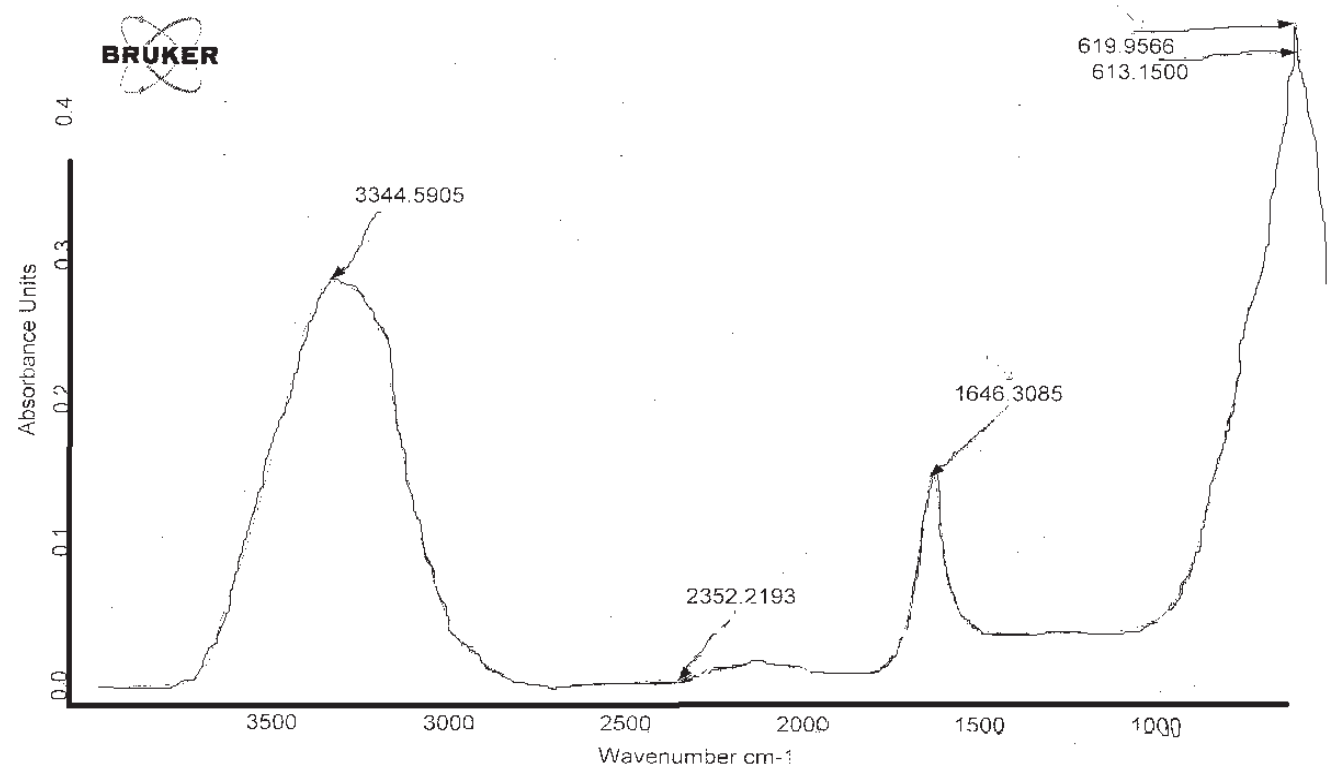

b)

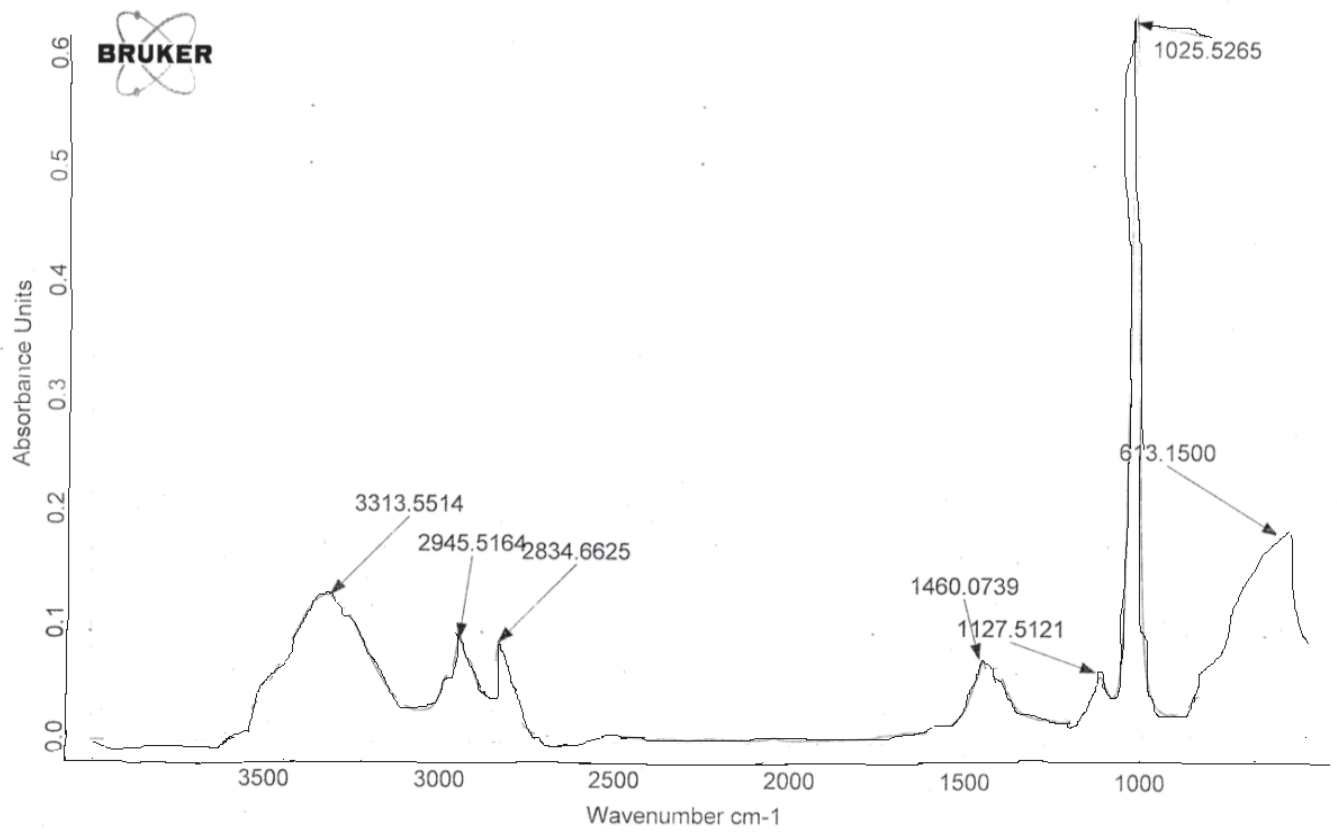

Fig. 2. FTIR spectrum of synthetic dye wastewater before a) and after b) biological treatment by P. chrysosporium. 


\section{Conclusions}

Biodegradation was found to be a more efficient technology in terms of its eco-friendly nature and complete degradation of almost all dangerous dyes. Phanerochaete chrysosporium was found to be the best candidate for detoxifying the synthetic dye wastewater under study. Lignin peroxidase of Phanerochaete chrysosporium was found to be responsible for detoxifying the wastewater under study. It can be concluded that Phanerochaete chrysosporium could be the best candidate for detoxification/mineralization of toxic dyes.

\section{Acknowledgments}

The present experimental work was done in an applied chemistry laboratory under the kind supervision of Dr. Shumaila Kiran, who is the principal investigator of the Higher Education Commission in Islamabad, Pakistan, as funded project No. PM-IPFP/HRD/ HEC/2012/2784. The authors are thankful to HEC for providing funds to carry out the present part of our study.

\section{Conflict of Interest}

All authors declare no conflict of interest.

\section{References}

1. SINGH R.L., SINGH P.K., SINGH, R.P. Enzymatic decolorization and degradation of azo dyes - A review. Int. Biodeter. Biodegrad. 104, 21, 2015.

2. VIJAYANAND S., MISRA M. Decolourization of industrial dyes using ascomycetes and mucor species. Int. J. Pharma. Bio-Sci. 8 (2), 285, 2017.

3. RAWAT D., MISHRA V., SHARMA R.S. Detoxification of azo dyes in the context of environmental processes. Chemosphere, 155, 591, 2016.

4. KIRAN S., ALI S., ASGHER M. Degradation and mineralization of azo dye reactive blue 222 by sequential photo-Fenton's oxidation followed by aerobic biological treatment using white rot fungi. Bull. Environ. Contamin. Toxicol. 90 (2), 208, 2013.

5. PEZZELlA C., MACELlARO G., SANNIA G., RAGANATI F., OLIVIERI G., MARZOCCHELLA A., PISCITELL, A. Exploitation of Trametes versicolor for bioremediation of endocrine disrupting chemicals in bioreactors. PloS one. 12 (6), 0178758, 2017.

6. ZHANG C., LI Y., WANG C., NIU L. CAI W. Occurrence of endocrine disrupting compounds in aqueous environment and their bacterial degradation: A review. Crit. Rev. Environ. Sci. Technol. 46, 1, 2016.

7. SINGH L. SINGH V.P. Decolourization of Azo (Acid Red) and Anthraquinonic (Basic Blue) dyes by the fungus Aspergillus flavus. Int. J. Biomed. Engng. Clin. Sci. 3 (1), 1, 2017.
8. YANG P., SHI W., WANG H., LIU H. Screening of freshwater fungi for decolorizing multiple synthetic dyes. Braz. J. Microbiol. 47 (4), 828, 2016.

9. PEREZ S.R., ODUARDO N.G., SAVON R.C.B., BOIZAN M.F., AUGUR C. Decolourization of Mushroom farm wastewater by Pleurots ostreatus, Biodegradation, 19 (4), $519,2008$.

10. ASGHER M., SHAH S.A., ALI M., LEGGE R. Decolorization of some reactive textile dyes by white rot fungi isolated in Pakistan. World J. Microbiol. Biotechnol. 22 (1), 89, 2006.

11. SEKULJICA N.Z., PRLAINOVIC N.Z., STEFANOVIC A.B., ZUZA M.G., CICKARIC D.Z., MIJIN D.Z., KNEZEVIC-JUGOVIC Z.D. Decolorization of anthraquinonic dyes from textile effluent using horseradish peroxidase: optimization and kinetic study. Sci. World J. 371625, 2015.

12. QIN X., SUN X., HUANG H., BAI Y., WANG Y., LUO H., SU X. Oxidation of a non-phenolic lignin model compound by two Irpex lacteus manganese peroxidases: evidence for implication of carboxylate and radicals. Biotechnol. Biofuels. 10 (1), 103, 2017.

13. MISHRA B., KUMBHARE L.B., JAIN V.K., PRIYADARSINI K.I. Pulse radiolysis studies on reactions of hydroxyl radicals with selenocystine derivatives. The J. Phys. Chem. B 112 (14), 4441, 2008.

14. DATTA R., KELKAR A., BARANIYA D., MOLAEI A., MOULICK A., MEENA R.S., FORMANEK P. Enzymatic Degradation of Lignin in Soil: A Review. Sustainability, 9 (7), 1163, 2017.

15. SU Y., XIAN H., SHI S., ZHANG C., MANIK S.M.N., MAO J., ZHANG G., LIAO W., WANG Q., LIU H. Biodegradation of lignin and nicotine with white rot fungi for the delignification and detoxification of tobacco stalk. BMC Biotechnol. 16, 81, 2016.

16. KIRAN S., ALI S., ASGHER M., ANWAR F. Comparative study on decolorization of reactive dye 222 by white rot fungi Pleurotus ostreatus IBL-02 and Phanerochaete chrysosporium IBL-03. Afr. J. Microbiol. Res. 6, 3639, 2012.

17. NASEER A., NOSHEEN S., KIRAN S., KAMAL S., JAVAID M.A., MUSTAFA M., TAHIR A. Degradation and detoxification of Navy Blue CBF dye by native bacterial communities: an environmental bioremedial approach. Desalin. Water Treat. 57 (50), $24070,2016$.

18. KIRAN S., ALI S., ASGHER M., SHAHID S.A. Photofenton process: Optimization and decolourization and mineralization of reactive blue 222 dye. J. Environ. Sci. Water Resour. 1, 267, 2012.

19. KIRAN S., ADEEL S., NOSHEEN S., HASSAN A., USMAN M., RAFIQUE M.A. Recent trends in textile effluent treatments: A review. Adv. Mater. Wastewater Treat. 29, 2017.

20. GULZAR T., HUMA T., JALAL F., IQBAL S., ABRAR S., KIRAN S., RAFIQUE, M.A. Bioremediation of Synthetic and Industrial Effluents by Aspergillus niger Isolated from Contaminated Soil Following a Sequential Strategy. Molecules, 22 (12), 2244, 2017.

21. RANI B., KUMAR V., SINGH J., BISHT S., TEOTIA P., SHARMA S., KELA R. Bioremediation of dyes by fungi isolated from contaminated dye effluent sites for biousability. Braz. J. Microbiol. 45 (3), 1055, 2014.

22. MORE T.T., YAN S., TYAGI R.D., SURAMPALLI R.Y. Potential use of filamentous fungi for wastewater sludge treatment. J. Biores. Technol. 101, 7691, 2010. 
23. LADE H., KADAM A., PAUL D., GOVINDWAR S. Biodegradation and detoxification of textile azo dyes by bacterial consortium under sequential microaerophilic/ aerobic processes. EXCLI J. 14, 158, 2015.

24. MARTORELL M.M., ROSALES-SORO M.D., PAJOT M.H.F., DE-FIGUEROA L.I. Optimization and Mechanisms for Biodecoloration of a Mixture of dyes by Trichosporona kiyoshidainum HP 2023. Environ. Technol. $1,2017$.

25. LORESTANI H., TAHMASBI H., MOGHARABI M., AMERI A., FARAMARZI M.A. Studies on the laccasemediated decolorization, kinetic, and microtoxicity of some synthetic azo dyes. J. Environ. Health Sci. Engng. 14 (1), 7, 2017.

26. RADHA K.V., REGUPATHI A., ARUNAGIRI T., MURUGESAN T. Decolourization studies of synthetic dyes using Phanerochaete chrysosporium and their kinetics, Process Biochemistry. J. Biol. Chem. 40, 3337, 2005.

27. FU Y., VIRARAGHAVAN T. Fungal decolorization of dye wastewaters: a review. Biores. Technol. 79, 251, 2001.

28. BALAN D.S.C., MONTERIO R.T.R. Decolourization of textile dye indigo dye by lignolytic fungi. J. Biotechnol. 89, 141, 2001.
29. SINGH S., PAKSHIRAJAN K., DAVEREY A. Enhanced decolourization of Direct Red 80 dye by the white rot fungus. Phanerocheate chrysosporium employing sequential design of experiments. Biodegradation, 21 (4), 501, 2010.

30. ASHRAFI S.D., REZAEI S., FOROOTANFAR H., MAHVI A.H., FARAMARZI M.A. The enzymatic decolorization and detoxification of synthetic dyes by the laccase from a soil-isolated ascomycete, Paraconiothyrium variabile. Int. Biodeter. Biodegrad. 85, 173, 2013.

31. SALAR R.K., ROHILLA S.K., ROHILLA J.K. Decolorization of Reactive Black HFGR by Aspergillus sulphureus. Res. J. Recent Sci. 1 (1), 55, 2012.

32. CHATHA S.A.S., KIRAN S., GULZAR T., KAMAL S., GHAFFAR A., CHATHA M.N. Comparative study on decolorisation and mineralisation of synthetic and real textile effluents using advanced oxidation processes, Oxid. Commun. 39 (2), 1604, 2016.

33. BRUSCHWEILER B.J., KÜNG S., BURGI D., MURALT L., NYFELER E. Identification of non-regulated aromatic amines of toxicological concern which can be cleaved from azo dyes used in clothing textiles. Regul. Toxicol. Pharmacol. 69, 263, 2014. 